\title{
Sistem Retribusi Parkir Sebagai Pengawasan Pendapatan Asli Daerah Kabupaten
} Cilacap

\author{
Cahya Vikasari ${ }^{a}$ \\ ${ }^{a}$ Politeknik Negeri Cilacap, Jl.Dr. Soetomo No.1 Sidakaya, Cilacap 53212, Indonesia
}

\section{INFORMASI ARTIKEL}

Sejarah Artikel:

Diterima Redaksi: 17 April 2018

Revisi Akhir: 09 Januarit 2019

Diterbitkan Online: 30 April 2019

\section{KATA KUNCI}

Retribution,

waterfall,

parking.

\section{KORESPONDENSI}

Telepon: (0282) 533329

E-mail: cvikasari@gmail.com

\section{A $\quad$ B $\quad \mathbf{S}$ T $\mathbf{R}$ A $\mathbf{C}$ T}

\section{PENDAHULUAN}

Otonomi daerah menempatkan pemerintah daerah harus mampu menunjukkan peran aktif daerah dalam membiayai dan mengelola serta mengatur pemerintahannya sendiri, termasuk dalam hal mengatur dan memanfaatkan sumber-sumber daya yang berpotensi memberikan pemasukan kas pada pemerintahan daerah. Untuk menjalankan dan membiayai pemerintahan daerah tentu dibutuhkan sebuah anggaran yang mampu menggerakkan fungsi tersebut. Sumber pendapatan dari daerah akan berperan sangat penting, sehingga pemerintah daerah harus mampu mengolah dan menilai sumber-sumber daya dalam pendapatan daerah sehingga dapat dimanfaatkan dengan baik sehingga dapat meningkatkan kesejahteraan sosial masyarakat yang ada didaerah tersebut [1]. Kontribusi yang ada dalam pendapatan daerah seperti pajak dan retribusi daerah akan berperan penting dalam mendukung peningkatan pendapatan asli dari sebuah daerah. Pajak yang dapat diterapkan dalam sebuah daerah serta retribusi parkir salah satunya mempunyai prospek cerah dalam meningkatkan pendapatan asli daerah [2]. Beberapa retribusi yang dapat dikelola oleh daerah yaitu retribusi jasa yang didalamnya terdapat pengelolaan retribusi pelayanan kesehatan, retribusi parkir, retribusi pasar.
Dalam pengelolaan retribusi parkir masih terdapat permasalahan yang terjadi diantaranya, Dinas Perhubungan sulit mengetahui informasi tentang hutang setoran retribusi, biaya operasional untuk menggaji pegawai yang diberikan tugas untuk menganalisis pendapatan retribusi cukup tinggi, pengelolaan data transaksi yang ada di UPTD perparkiran belum tersimpan dengan baik. Permasalahan tersebut dapat mengakibatkan terjadi kehilangan data dan sulitnya melakukan pengawasan terhadap penerimaan pendapatan daerah dari perparkiran sehingga dapat menjadi celah kecurangan dalam pengelolaan data perparkiran , kurang efisien dari segi waktu dalam penyusunan laporan karena data setoran retribusi tidak langsung direkap, kegiatan pengolaan transaksi dalam mengelola data retribusi parkir yang ada di UPTD perparkiran belum berjalan dengan baik.

Diperlukan adanya sistem untuk membantu pengelolaan retribusi parkir di Dinas Perhubungan. Tujuan dari penelitian ini adalah membangun sistem dalam mengelola retribusi parkir yang dapat membatu Dinas Perhubungan dalam melakukan pengawasan terhadap penerimaan retribusi parkir di kabupaten Cilacap. 
Penelitian sebelumnya dilakukan oleh wahyudianto dengan judul "Perancangan Sistem Informasi Parkir Pada Dinas Perhubungan Komunikasi Dan Informatika Kabupaten Pacitan" yang membahas tentang sasaran pembangunan daerah kabupaten Pacitan melalui Dinas Perhubungan Komunikasi dan Informatika akan diarahkan kepada upaya dalam penyelenggaraan pelayanan yaitu jasa transportasi, komunikasi dan informatika sehingga dapat mewujudkan masyarakat yang demokratis dan sejahtera. Tujuan dari penelitian ini adalah merancang sistem yang dapat digunakan untuk mengelola data parkir yang ada di Dinas Perhubungan dan Informatika pada kabupaten Pacitan. Hasil penelitian yaitu membuat rancangan system yang dapat mempermudah informasi pada pihak Dinas Perhubungan Komunikasi dan Informatika kabupaten Pacitan dalam mengetahui data yang ada misalnya data transaksi [3].

Penelitian sebelumnya dilakukan oleh Rakasiwih dkk, dengan judul Sistem Informasi Peramalan Pendapatan Retribusi Parkir Dinas Perhubungan Kota Palembang. Tujuan dari penelitian mengenai peramalan pendapatan retribusi parkir ini yaitu untuk membantu UPTD perparkiran Dinas Perhubungan kota Palembang untuk mengoptimalisasi pendapatan asli daerahnya. Sistem yang dibangun dapat membantu dalam mengelola perizinan parkir, mengelola transaksi retribusi parkir dan dapat melakukan peramalan pendapatan retribusi parkir pada tahun selanjutnya. Data retribusi parkir akan dijadikan titik awal dalam peramalan pendapatan pada tahun berikutnya. Statistika akan dilakukan untuk menganalisa peramalan pendapatan retribusi dengan melakukan analisa menggunakan data berkala dengan metode kuadrat terkecil. Tidak akan terjadi redundasi kegiatan saat pengelolan retribusi parkir dibantu dengan sebuah system, mengetahui lokasi mana yang belum membayar retribusi parkir, serta dapat meramalkan pendapatan retribusi parkir selanjutnya [4].

\section{METODE}

\subsection{Bahan Penelitian}

Bahan penelitian yang digunakan antara lain :

\section{A. Objek Penelitian}

Objek penelitian ini adalah Dinas Perhubungan sebagai instansi pengelola data perparkiran yang ada di wilayah kabupaten Cilacap.

\section{B. Data Penelitian}

Data yang mendukung dalam melakukan penelitian ini adalah data primer dan data sekunder, yaitu :

a. Data Primer adalah data yang diperoleh langsung dari objek lokasi parkir, data pegawai parkir, data transaksi, proses bisnis retribusi parkir kabupaten Cilacap.

b. Data Sekunder adalah data yang diperoleh dengan membaca dan mempelajari referensi yang berkaitan dengan penelitian yang dilakukan.

\subsection{Tahap Pengembangan Sistem}

Tahap pengembangan perangkat lunak yang dilakukan penulis dalam membangun sistem retribusi parkir sebagai pengawasan penerimaan pendapatan asli daerah yaitu menggunakan metode waterfall. Metode waterfall (gambar 1) ini merupakan metode

2 Cahya Vikasari yang menggunakan pendekatan alur hidup sebuah perangkat lunak secara sekuensial atau secara berurut mulai dari tahap analisis, tahap desain, tahap pengkodean, tahap pengujian, tahap support [5].

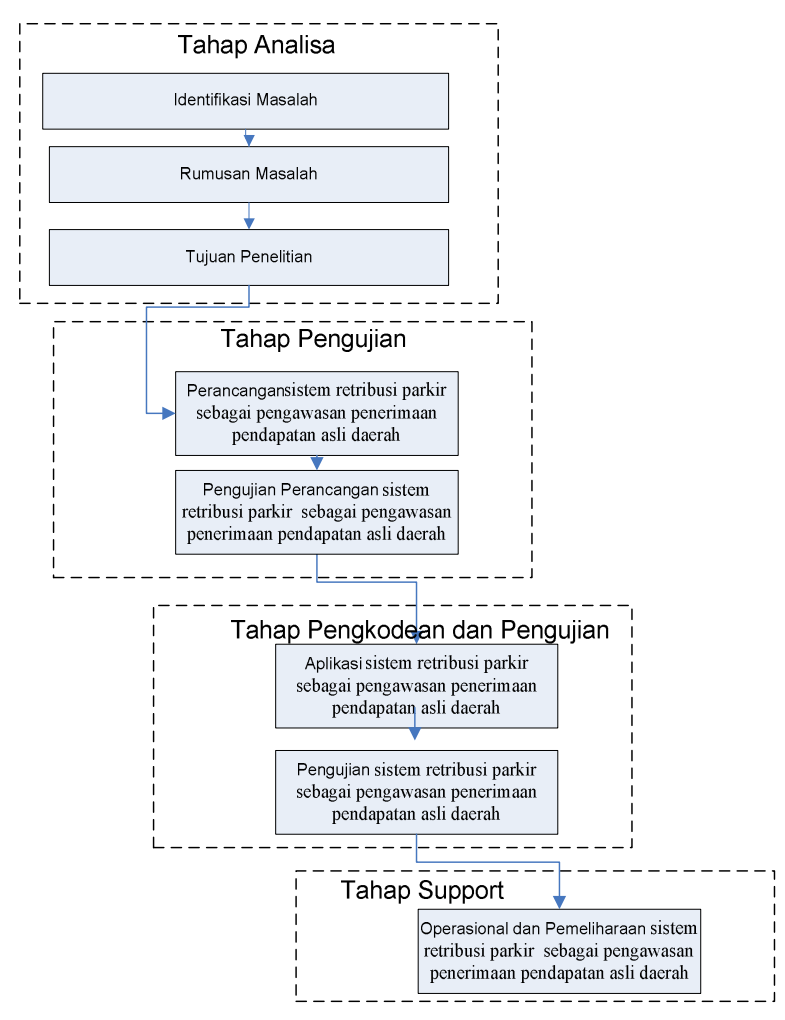

Gambar 1. Tahap Pengembangan Sistem

Studi lapangan serta studi literatur dilakukan pada tahap pertama yaitu tahap analisis dengan tujuan untuk mengetahui permasalahan yang ada di Dinas Perhubungan yaitu bidang perparkiran serta untuk menggali data yang dibutuhkan dalam penelitian mengenai sistem retribusi parkir sebagai pengawasan penerimaan pendapatan asli daerah. Permasalahan yang ada adalah belum adanya sistem yang membantu manajemen pengelolaan data parkir yang ada di kabupaten Cilacap, sehingga terjadi adanya kerumitan dalam mengelola dan merekap hasil dari hasil dana parkir yang diperoleh Dinas Perhubungan untuk mengetahui pendapatan asli daerah kabupaten Cilacap. Pendataan yang dilakukan adalah mendata pegawai atau karyawan yang melakukan pengelolaan data, melakukan pendataan lokasi parkir yang diizinkan untuk kegiatan perparkiran, mendapatkan data aturan retribusi parkir kendaraan yang berlaku, data transaksi yang ada dalam pengelolaan data retribusi parkir. Langkah selanjutnya adalah menganalisis bisnis proses di Dinas Perhubungan, terutama yang berkaitan dengan pengelolaan data perparkiran. Metode yang digunakan untuk menganalisis bisnis proses meliputi studi lapangan dengan wawancara secara langsung. Setelah kebutuhan akan alur kerja manajemen pengelolaan data retribusi didapatkan, dilanjutkan dengan mengumpulkan data yang diperlukan sesuai dengan penjelasan pada bahan penelitian.

Studi lapangan pada Dinas Perhubungan mengenai retribusi parkir kabupaten Cilacap dilakukan untuk memperoleh data dan fakta mengenai retribusi parkir yaitu dengan mengadakan wawancara langsung dengan pihak-pihak yang berwenang dan 
berhubungan dengan pokok-pokok permasalahan yang diteliti. Studi literatur dilakukan dengan mengeksplorasi penelitian terdahulu yang berkaitan dengan pengelolaan data retribusi parkir. Perumusan masalah dijabarkan dari hasil studi lapangan dan studi literatur, sehingga akan ditentukan tujuan dari penelitian mengenai retribusi parkir

\section{HASIL DAN PEMBAHASAN}

\subsection{Proses Bisnis}

Proses bisnis dari sistem retribusi parkir yang dilakukan oleh Dinas Perhubungan kabupaten Cilacap yang akan dikembangkan tidak mengubah alur kerja yang sudah ada. Dinas Perhubungan kabupaten Cilacap sudah memiliki aturan atau proses bisnis pengelolaan retribusi parkir. Admin mengelola data parkir, mengelola data karyawan yang mengelola data retribusi parkir, mengolah data user yang mempunyai hak akses masuk ke sistem retribusi parkir, dan admin diberikan hak untuk melihat data retribusi parkir. Izin lokasi parkir dilakukan oleh pegawai lalu kemudian memproses izin parkir tersebut dan mengaktifkan lokasi parkir jika izin lokasi parkir diberikan. Lokasi perparkiran juga akan dicek oleh pegawai untuk mengetahui lokasi parkir yang masih aktif atau sudah tidak aktif. Kepala Dinas Perhubungan sebagai manajemen tingkat atas dapat melihat laporan retribusi setiap bulannya. Informasi dari laporan retribusi parkir akan menjadi dasar bagi Kepala Dinas Perhubungan untuk mengambil kebijakan selanjutnya agar dana retribusi parkir untuk daerah kabupaten Cilacap dapat tercapai sesuai target. Proses bisnis dari sistem retribusi parkir sebagai pengawasan penerimaan pendapatan asli daerah (gambar 2) .

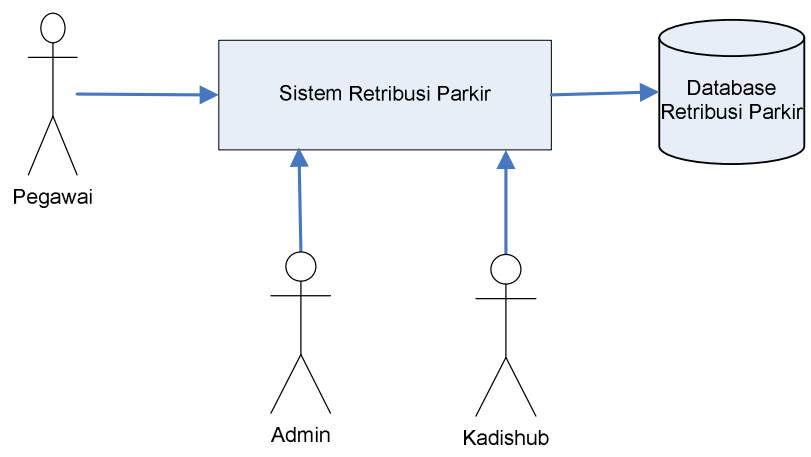

Gambar 2. Proses Bisnis Sistem Retribusi Parkir Sebagai Pengawasan Penerimaan Pendapatan Asli Daerah

\subsection{Analisis Kebutuhan}

Tahap analisa kebutuhan dilaksanakan untuk mendapatkan informasi yang dibutuhkan, model serta spesifikasi mengenai perangkat lunak atau software yang dibutuhkan oleh pengguna. Keterlibatan kedua belah pihak yaitu klien dan pembuat aplikasi sangat dibutuhkan dalam tahap ini [6]. Analisis kebutuhan dalam pengembangan sistem yang dilakukan yaitu functional requirement dan non functional requirement.

\section{Functional requirement}

Functional requirement didapatkan dari hasil analisa kebutuhan pengguna dalam sistem retribusi parkir sebagai pengawasan penerimaan pendapatan asli daerah. Berikut merupakan functional requirement dalam membangun sistem retribusi parkir sebagai pengawasan penerimaan pendapatan asli daerah.

Kadishub: 1. Mempunyai hak akses untuk melihat laporan retribusi parkir

2. Laporan izin lokasi parkir

Pegawai : 1. Mempunyai hak akses untuk mengolah data retribusi parkir

2. Mengolah data izin lokasi parkir

3. Melihat status permohonan lokasi parkir.

4. Melihat status izin lokasi yang masih aktif dan tidak aktif.

Admin : 1 . Mempunyai hak akses untuk mengolah data parkir

2. Mengolah data karyawan

3. Mengolah data user

4. Melihat data retribusi parkir.

\section{Non-functional requirement}

a. Data Base

Basis Data yang bersifat Open Source yang paling ringan dan telah teruji kehandalannya dalam mengelola informasi dalam jumlah besar adalah $M y S Q L$

b. API (Application Programming Interface)

Dalam pengembangan sistem retribusi parkir sebagai pengawasan penerimaan pendapatan asli daerah, perlu diimplementasikan API yang handal dan mudah dikembangkan salah satunya adalah bahasa $\mathrm{C}$ menggunakan microsoft visual studio.

\subsection{Perancangan}

1. Use Case Diagram

Perancangan sistem retribusi parker sebagai pengawasan penerimaan pendapatan asli daerah dibuat sesuai dengan analisis kebutuhan yang diperoleh dalam tahapan analisis. Pembuatan sistem retribusi parker sebagai pengawasan penerimaan pendapatan asli daerah ini, penulis menggunakan pemodelan UML. UML (Unified Modeling Language) merupakan bahasa pemodelan untuk system yang mempunyai paradigm berorientasi objek. Pemodelan UML digunakan untuk menyederhanakan permasalahan yang lebih kompleks sehingga lebih mudah dipahami dan lebih mudah dipelajari [7]. Diagram UML yang digunakan oleh penulis salah satunya adalah Use Case Diagram. Use Case merupakan pemodelan untuk kelakuan (behavior) sistem informasi yang akan dibuat. Use Case melakukan pendeskripsian sebuah interaksi antara satu atau lebih aktor dengan sistem informasi yang akan dibuat. 


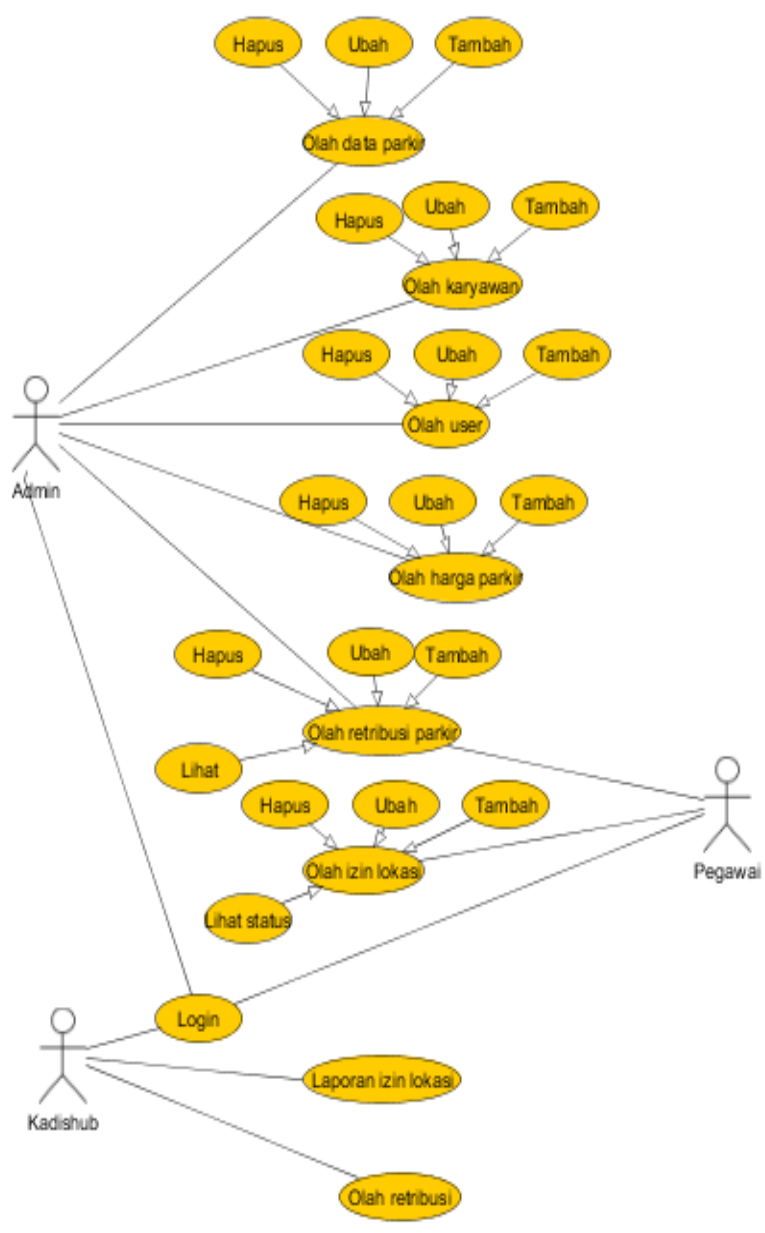

Gambar 3. Use Case Diagram
Use Case Diagram digunakan untuk mengetahui fungsi apa saja yang ada di dalam sebuah sistem informasi dan siapa saja yang berhak menggunakan fungsi-fungsi itu [5]. Gambar 3 merupakan diagram Use Case dalam merancang sistem retribusi parkir sebagai pengawasan penerimaan pendapatan asli daerah .

\section{Sequence Diagram}

Sequence Diagram digunakan untuk menggambarkan interaksi antara objek di dalam dan di sekitar system yang akan dibangun antara lain pengguna dan form aplikasi berupa message yang digambarkan terhadap waktu. Sequence Diagram terdiri dari penggambaran waktu yaitu dimensi vertikal dan objek yang terkait yang digambarkan dengan dimensi horizontal. Skenario yang terjadi dalam aplikasi yang dibangun dapat digambarkan dengan diagram sequence begitu pula dengan respon dan event untuk menghasilkan output tertentu dalam sistem. Diagram sequence berasosiasi dengan diagram use case serta memperlihatkan tahap demi tahap segala sesuatu yang akan pasti akan terjadi dalam menghasilkan sesuatu dalam diagram use case[8].

Sequence diagram pengelolaan data lokasi parkir digunakan untuk mendata lokasi-lokasi parkir yang diberikan izin (gambar 4). Sequence diagram pengelolaan data karyawan digunakan untuk mendata karyawan yang terlibat dalam pengelolaan data retribusi parkir (gambar 5). Sequence diagram pengelolaan data izin lokasi digunakan untuk mengelola perizinan lokasi parkir (gambar 6). Sequence diagram pengelolaan data retribusi parkir digunakan untuk mengelola pendapatan transaksi retribusi parkir daerah (gambar 7).

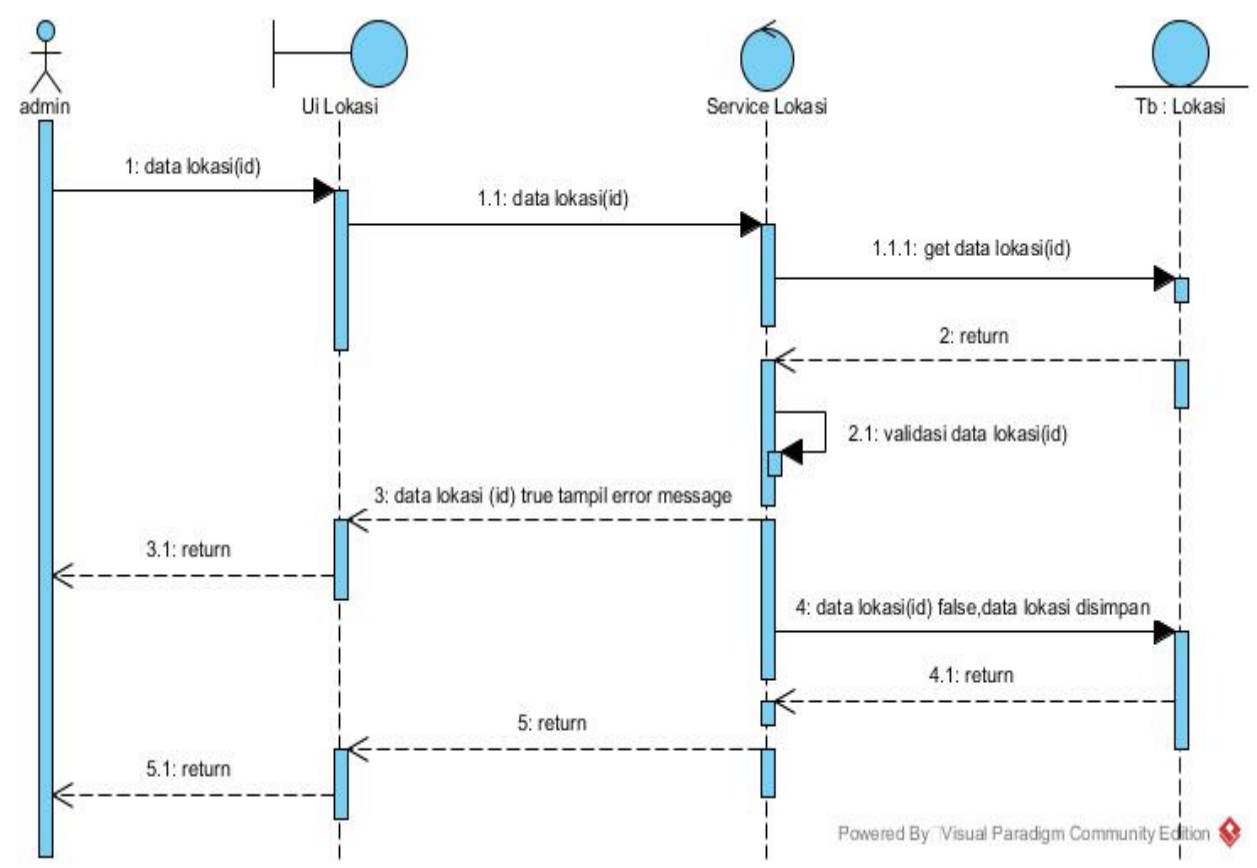

Gambar 4. Sequence Diagram Pengelolaan Data Lokasi 


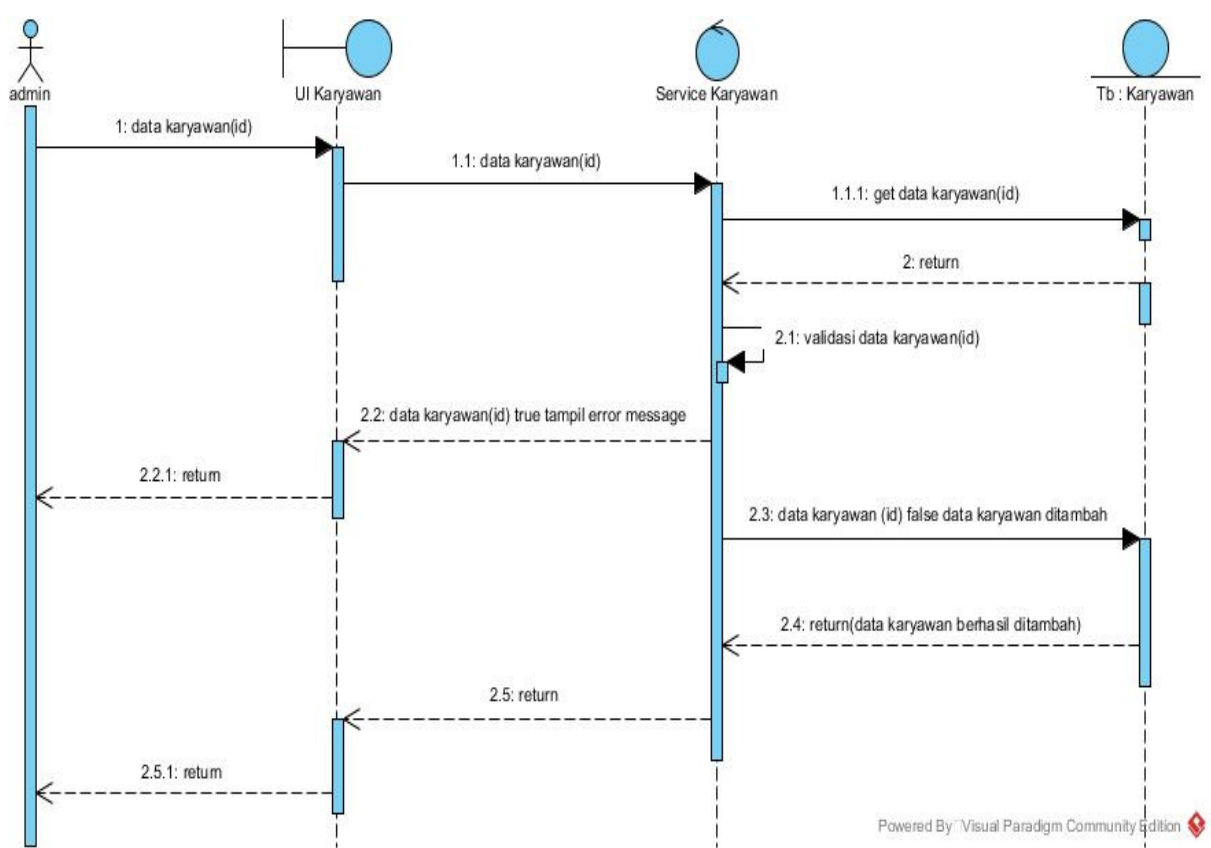

Gambar 5. Sequence Pengelolaan Data Karyawan

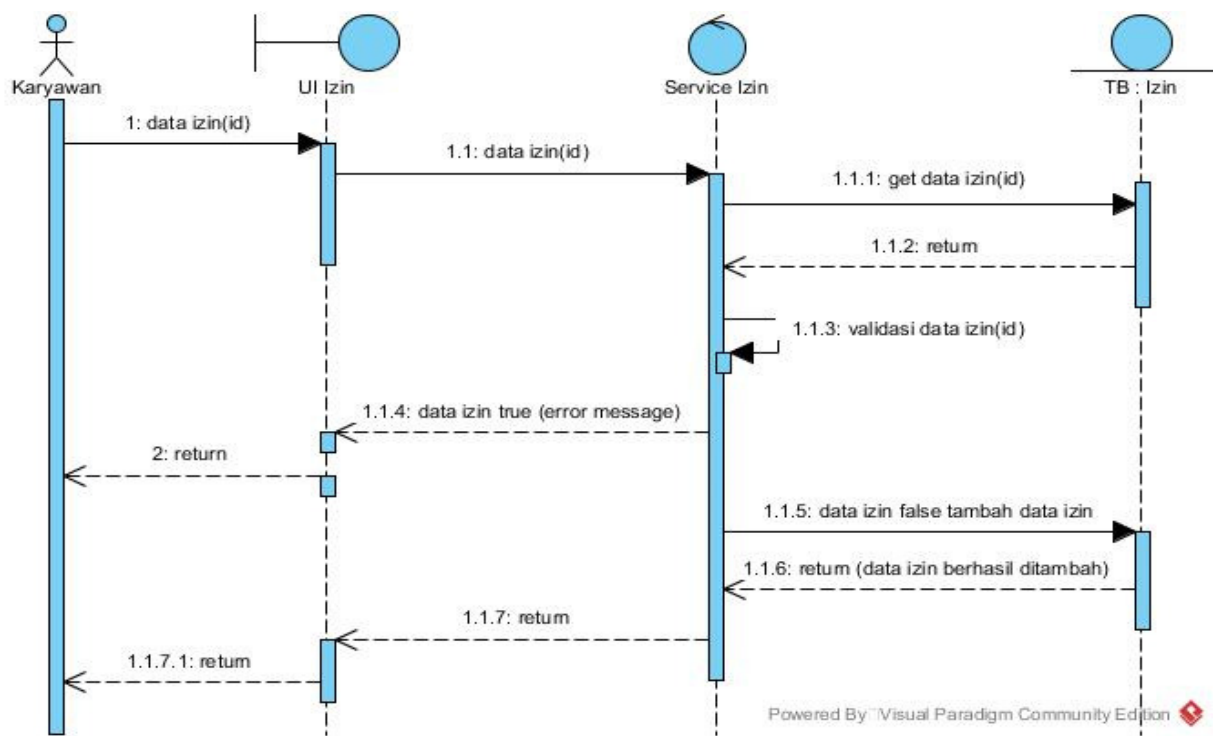

Gambar 6. Sequence Diagram Pengelolaan Data Izin lokasi

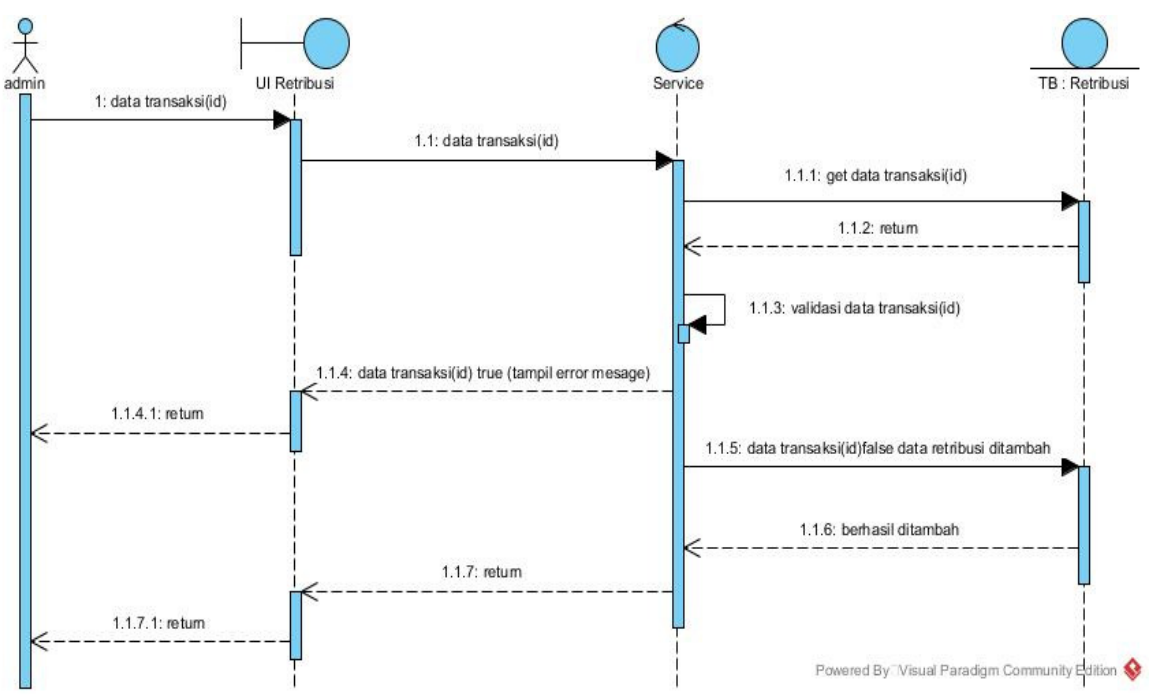

Gambar 7. Sequence Diagram Olah Data Retribusi Parkir 


\section{Class Diagram}

Struktur sistem dari pendefinisian kelas-kelas dapat digambarkan dengan diagram class. Kelas memiliki atribut, metode atau operasi. Diagram kelas mendefinisikan jenis objek dalam sebuah sistem dan hubungan statis yang ada dalam hubungan antar objek tersebut [9]. Di bawah ini merupakan class diagram untuk menggambarkan struktur sistem retribusi parkir sebagai pengawasan penerimaan pendapatan asli daerah (gambar 8).

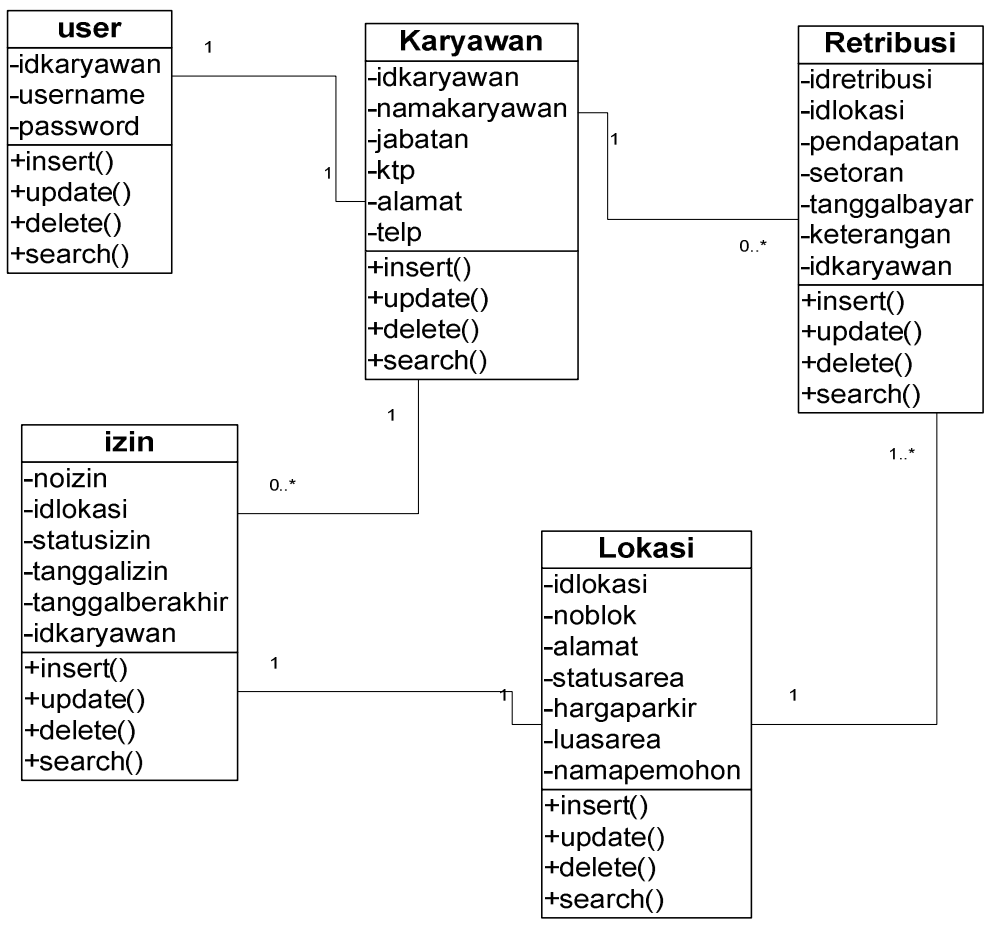

Gambar 8. Class Diagram

\subsection{Antarmuka Sistem}

Antar muka sebuah sistem merupakan mekanisme komunikasi antara user dengan aplikasi itu sendiri. Antarmuka sebuah sistem dapat menerima informasi dari user serta memberikan informasi pada user untuk membantu mengarahkan alur penelusuran sebuah masalah sampai ditemukan jalan keluar atau solusi [10].

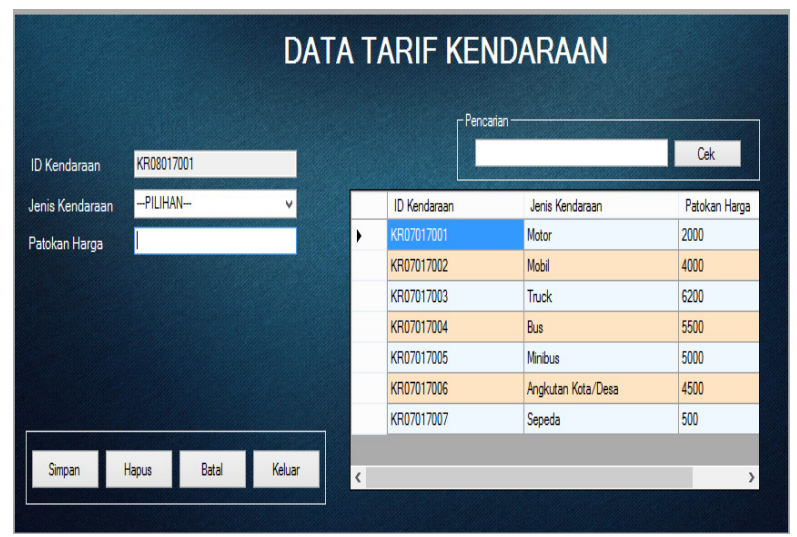

Gambar 9. Antarmuka Pengolahan Data Tarif Kendaraan

Tampilan antarmuka pengolahan tarif kendaraan sesuai dengan peraturan yang berlaku sehingga Dinas Perhubungan dapat memberikan informasi yang pasti mengenai tarif kendaraan yang dapat diberlakukan di kabupaten Cilacap. Hal ini dapat mengurangi kecurangan di lapangan atau lokasi parkir mengenai tarif kendaraan yang sebenarnya (gambar 9).

6 Cahya Vikasari

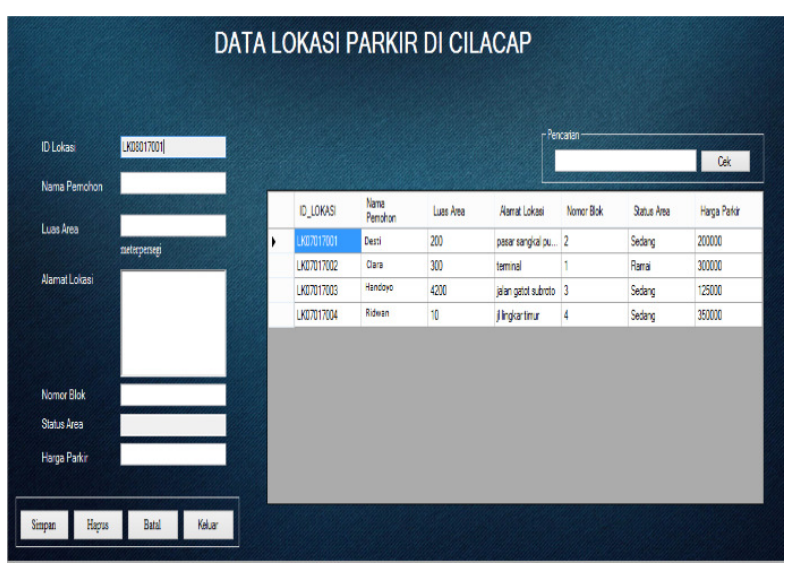

Gambar 10. Tampilan Sistem Pengolahan Data Lokasi Parkir

Tampilan antarmuka untuk mengolah data lokasi parkir yang ada di kabupaten Cilacap, sebagai dasar untuk melakukan monitoring terhadap perolehan transaksi retribusi parkir. Semua titik lokasi parkir yang ada di kabupaten Cilacap diharapkan dapat dimasukan ke dalam database sistem agar data yang ada dapat lebih akurat (gambar 10).

Tampilan antarmuka pengelolaan data karyawan yang akan menghandle transaksi perparkiran yang ada di Dinas Perhubungan kabupaten Cilacap. Pengelolaan data diri karyawan yang diisi ditambahkan dengan user id dan password untuk proses login (gambar 11). 


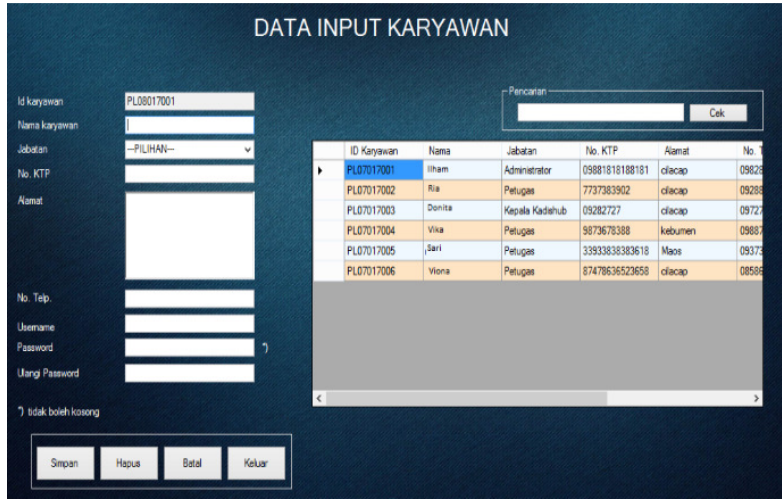

Gambar 11. Antarmuka Pengolahan Data Input Karyawan.

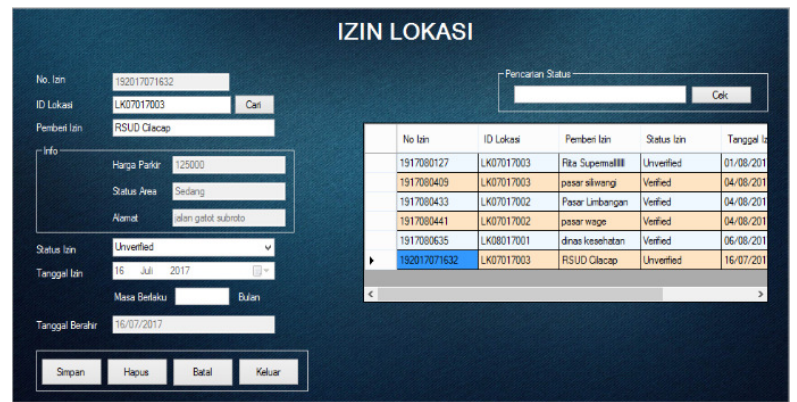

Gambar 12. Halaman Pengolahan Data Izin Lokasi.

Pegawai dapat mengolah data izin lokasi parkir yang dapat dibuat lahan parkir yang akan menambah transaksi retribusi parkir dan berimbas pada pendapatan daerah kabupaten Cilacap (gammbar 12).

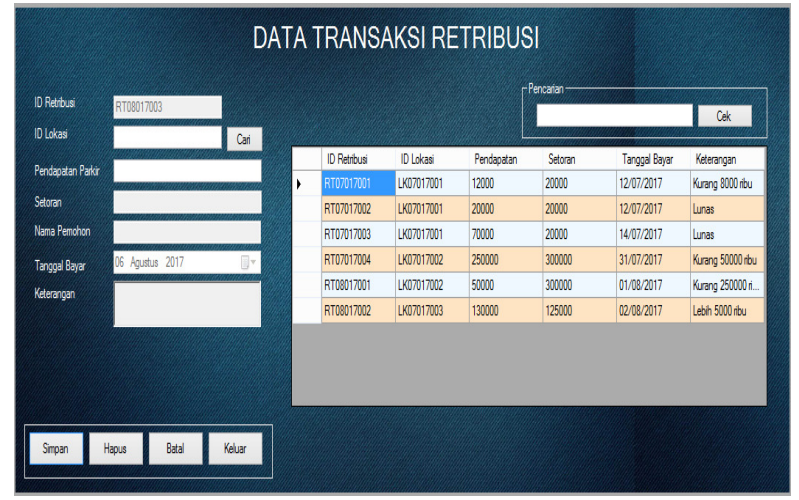

Gambar 13. Halaman Pengolahan Data Retribusi.

Pengelolaan data retribusi harus dilakukan secara detail oleh pegawai yang mengelola. Fungsi pengawasan dan kontrol dari pendapatan daerah khususnya perparkiran dapat dilakukan dengan pengolahan data transaksi retribusi yang akurat dan up to date (gambar 13).

Proses pengelolaan data dengan menggunakan aplikasi retribusi parkir dimulai dengan melakukan pengelolaan data dasar, yaitu pengelolaan data karyawan, lokasi parkir, mengelola data user. Selanjutnya dilakukan permohonan izin parkir yang akan dilakukan oleh pegawai dinas perhubungan dan selalu melakukan pengecekan terhadap lokasi parkir yang masih aktif dan yang sudah tidak aktif. Dalam pengelolaan data retribusi harus dilaksanakan secara rutin sehingga tidak akan terjadi kekeliruan data retribusi parkir. Data rutin dilakukan untuk menunjang fungsi pengawasan yang akan dilakukan oleh kepala dinas perhubungan.

Tabel 1. Perbandingan Sistem Lama dengan Sistem Baru

\begin{tabular}{|c|c|}
\hline $\begin{array}{l}\mathbf{N} \\
\mathbf{0}\end{array}$ & Sistem Lama \\
\hline 1 & $\begin{array}{l}\text { Pegawai mengisi data retribusi } \\
\text { parkir setiap harinya pada } \\
\text { buku retribusi parkir. Hal ini } \\
\text { dapat terjadi kehilangan data. }\end{array}$ \\
\hline 2 & $\begin{array}{l}\text { Pegawai mengisikan lokasi } \\
\text { parkir dan data yang lainnya } \\
\text { pada kegiatan retribusi parkir } \\
\text { yang ada di Cilacap pada } \\
\text { buku, sehingga menyulitkan }\end{array}$ \\
\hline
\end{tabular}

3 Proses ijin lokasi parkir dilakukan dengan melakukan pencatatan pada dokumen kertas dan mengecek status dari lokasi parkir masih tersedia atau tidak hal ini bisa terjadi lamanya proses ijin lokasi parkir dan kesalahan monitoring status lokasi parkir.

4 Laporan retribusi parkir Laporan akan dilakukan dilakukan secara manual oleh secara otomatis oleh pegawai dengan merekap satu sistem jika ada data persatu data transaksi retribusi transaksi retribusi parkir parkir.

5 Pegawai memberikan berkas Kepala Dinas laporan retribusi parkir ke Perhubungan melihat hasil kepala Dinas Perhubungan. laporan rekat hasil retribusi parkir melalui sistem.

6 Manajer merekap hasil Manajer cukup mengklik keputusan pelamar yang pelamar yang diterima diterima. atau ditolak dan sudah terekap secara otomatis oleh sistem

7 Bagian rekrutmen Pelamar yang diterima mengumumkan pelamar yang secara otomatis sudah diterima. Pelamar perlu dapat diakses oleh mengecek di lokasi. web.

Pengawasan dilakukan terhadap record dari data yang dimasukan dalam aplikasi dan disimpan dalam database sehingga kepala dinas perhubungan kabupaten Cilacap dapat mengetahui kinerja dari bagian yang mengelola data perparkiran sehingga sistem retribusi 
parkir dapat digunakan untuk pengawasan penerimaan pendapatan asli daerah kabupaten Cilacap dan dapat membatu dinas perhubungan dalam melakukan pengawasan terhadap penerimaan retribusi parkir di Kabupaten Cilacap.

Sistem ini juga dapat membantu mempermudah dalam pengolahan transaksi retribusi secara akurat dan up to date sehingga jika ada pihak yang membutuhkan informasi mengenai retribusi parkir, izin parkir, lokasi parkir tidak meragukan informasi yang ada pada aplikasi karena keakuratan data yang dapat dipertanggungjawabkan. Dukungan terhadap manajemen tingkat atas adalah membuat laporan yang dapat mempermudah analisa terhadap informasi yang ditampilkan dalam laporan retribusi perparkiran sehingga dapat digunakan sebagai bahan untuk pembuatan kebijakan mengenai pendapatan dari sektor perparkiran.

\subsection{Evaluasi Sistem}

Sistem baru yang telah diuji ini dibandingkan dengan sistem lama yang dilakukan secara manual. Berdasarkan Perbandingan sistem baru dengan sistem lama (tabel 1), dapat dilihat bahwa proses retribusi parkir menjadi lebih efektif dan efisien dengan menggunakan aplikasi untuk membantu pengelolaan data retribusi parkir. Pegawai tidak perlu melakukan rekap satu persatu karena proses perekapan akan dilakukan otomatis oleh sistem retribusi parkir yang ada di kabupaten Cilacap. Pengelolaan data yang rutin dilakukan akan membuat data yang akurat dan informasi yang didapatkan dari aplikasi retribusi parkir lebih uptodate.

Sistem aplikasi retribusi parkir ini akan menghasilkan laporan yang akan memberikan informasi perkembangan dari penerimaan pendapatan asli daerah khususnya retribusi parkir dan akan menjadi informasi yang berharga bagi kepala Dinas Perhubungan untuk membuat kebijakan sesuai dengan informasi yang didapatkan dari laporan yang ada. Fungsi pengawasan dan kontrol terhadap proses retribusi parkir juga secara tidak langsung merupakan nilai tambah dari aplikasi ini karena perubahan data pada aplikasi memperlihatkan bahwa pegawai yang mengelola data retribusi parkir telah menjalankan tugasnya.

\section{KESIMPULAN}

Berdasarkan hasil pembahasan tentang sistem retribusi parkir sebagai pengawasan penerimaan pendapatan asli daerah, diperoleh kesimpulan sebagai berikut:

1. Sistem retribusi parkir sebagai pengawasan penerimaan pendapatan asli daerah kabupaten Cilacap ini dapat membatu Dinas Perhubungan dalam melakukan pengawasan terhadap penerimaan retribusi parkir di kabupaten Cilacap.

2. Sistem dapat membantu dalam pengolahan transaksi retribusi secara akurat dan up to date.

3. Sistem dapat menampilkan laporan transaksi khususnya perparkiran sehingga dapat menjadi informasi sebagai bahan untuk pembuatan kebijakan mengenai pendapatan dari sektor perparkiran.

Setelah sistem retribusi parkir sebagai pengawasan penerimaan pendapatan asli daerah ini dibuat, ada beberapa saran perbaikan untuk kesempurnaan pengembangan sistem bagi penulis selanjutnya dimasa mendatang, agar sistem dapat ditambahkan dengan fitur grafik untuk melakukan analisis pendapatan retribusi parkir. Sistem kedepannya agar dapat diintegrasikan dengan beberapa pengelolaan data retribusi lainnya contohnya retribusi pasar atau yang lainnya yang disesuaikan dengan pendapatan daerah.

\section{DAFTAR PUSTAKA}

[1] Bayu, "Sumber Pendapatan Daerah dalam UndangUndang," 2017. .

[2] H. Said, S. Khairani, and Icha Fajriana, "Analisis penerimaan retribusi parkir dan pajak parkir di dinas pendapatan asli daerah kota palembang," STIE MDP, no. 14, pp. 1-9, 2016

[3] E. Wahyudianto, "Perancangan Sistem Informasi Parkir Pada Dinas Perhubungan Komunikasi dan Informatika Kabupaten Pacitan," Semin. Ris. Unggulan Nas. Inform. dan Komput. FTI UNSA, vol. 2, pp. 19-26, 2013.

[4] E. Rakasiwih and M. A. Fitriansyah, "Sistem Informasi Peramalan Pendapatan Retribusi Parkir Dinas Perhubungan Kota Palembang," STIMIK GI MDP, 2013.

[5] A.S Rosa and S. M, Modul Pembelajaran Rekayasa Perangkat Lunak (Terstruktur dan Berorientasi Objek). Bandung: Modula, 2011.

[6] mohumaralfaruq, "Analisis Kebutuhan," 2013.

[7] A. Nugroho, Rekayasa Perangkat Lunak Menggunakan UML \& Java. Yogyakarta: Adi Offset, 2009.

[8] Desi, "Sequence Diagram."

[9] Y. Sugiarti, Analisis dan Perancangan UML (Unified Modeling Languege). Yogyakarta: Graha Ilmu, 2013.

[10] B. Bahtiar, "Pengertian Interface," 2014.

\section{BIODATA PENULIS}

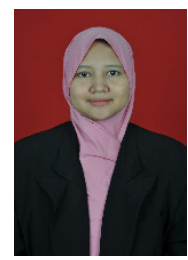

Cahya Vikasari

adalah dosen tetap jurusan teknik informatika Politeknik Negeri Cilacap. Penulis telah menempuh pendidikan sarjana informatika pada tahun 2007 dari program studi teknik informatika universitas Widyatama Bandung. Pendidikan pascasarjana ditempuh di program studi teknik elektro Universitas Gadjah Mada dengan spesialisasi teknologi informasi pada tahun 2011. Selama bekerja di Politeknik Negeri Cilacap pernah menjabat sebagai sekretaris jurusan teknik informatika dan menjadi sekretaris senat Politeknik Negeri Cilacap. Bidang informatika yang penulis tekuni adalah sistem informasi dan rekayasa perangkat lunak. Saat ini mengampu mata kuliah program professional, praktikum rekayasa perangkat lunak. 